\title{
TINJAUAN YURIDIS TERHADAP PENEGAKAN HUKUM TINDAK PIDANA PENYELUNDUPAN BIBIT LOBSTER
}

\author{
Made Agus Sanjaya, I Made Minggu Widyantara, Luh Putu Suryani \\ Fakultas Hukum, Universitas Warmadewa, Denpasar-Bali, Indonesia \\ agussanjaya806@gmail.com, mademineeu21@gmail.com, putuuryani099@gmail.com
}

\begin{abstract}
Abstrak
Penyelundupan sering terjadi mengingat fakta bahwa hasil laut sangat menarik. Dengan cara yang benar-benar mendasar, transaksi miliaran rupiah dapat dilakukan secara ilegal, sebagian besar dengan menghindari kantor bea masuk tarif yang berbeda yang diberikan oleh Beacukai. Saat ini Pemerintah sedang ber paya untuk mencegah penyelundupan hasil laut yang dilarang untu k diperdagangkan, karena selain merugikan Negara, ha1 ini bisa membuat biota laut minim dan kerugian hingga triliunan. Tujuan dari penelitian ini guna mengetahui pengaturan tentang larangan penangkapan bibit lobster dan penegakan hukum terhadap tindak pidana penyelundupan bibit lobster, tipe penelitian hukum Normatif. Sumber dari penelitian ini diperoleh melalui pendekatan-pendekatan dengan mengkaji berdasarkan peraturan perundang-undangan, prinsip-prinsip hukum, maupun doktrin-doktrin hukum untuk menyanggapi tema hukum yang dijumpai untuk mendapatkan pendapat, pemikiran serta pemahaman baru selaku aturan untuk menamatkan kejadian yang terjadi. Pedoman penangkapan benih lobster baru-baru ini diatur dalam Peratu ran Menteri KKP R1 Nomor 56 / PERMEN-KP / 2016 tentang Larangan Penangkapan dan atau Ekspor Lobster, Kepiting dan Kepiting. Pada tahun 2020 Kementerian Kelautan dan Perikanan Rl kembali memberikan pedoman Nomor 12 / PERM EN -KP / 2020 Tentang Pengelolaan Lobster, Kepiting dan Rajungan. yang secara tidak langsung membuka ekspor benih lobster di Indonesia.
\end{abstract}

Kata Kunci : Penyelundupan Bibit Lobster, Tindak Pidana Penyelundupan.

\begin{abstract}
Smuggling is common given the fact that marine products are very attractive. In a really basic way, transactions of billions of rupiah can be carried out illegally, mostly by avoiding the customs office of different rates provided by Customs. Currently, the Government is trying to prevent the smuggling of marine products that are prohibited for trading, because in addition to harming the State, this can result in minimal marine biota and losses of up to trillions. The purpose of this study is to determine the regulation regarding the prohibition of catching lobster seeds and law enforcement against the crime of smuggling lobster seeds, the type of normative legal research. The sources of this research are obtained through approaches by examining based on statutory regulations, legal principles, and legal doctrines to respond to legal themes encountered in order to obtain new opinions, thoughts and understandings as rules for ending events that occur. The sources of this research are obtained through approaches by examining based on statutory regulations, legal principles, and legal doctrines to respond to legal themes encountered in order to obtain new opinions, thoughts and understandings as rules for ending events that occur. The guidelines for catching lobster seeds have recently been regulated in the Minister of Marine Affairs and Fisheries Regulation No. 56 / PERMEN-KP / 2016 concerning the Prohibition of Catching and or Exporting Lobster, Crab and Crab. In 2020 the Ministry of Maritime Affairs and Fisheries of the Republic of Indonesia again provided guidelines Number 12 / PERM EN -KP / 2020 concerning Management of Lobster and Crabs. Which indirectly opens the export of lobster seeds in Indonesia.
\end{abstract} Keywords: Lobster Seed Smuggling, Smuggling Crime.

\section{PENDAHULUAN}

Negara Republik Indonesia yaitu sebuah Negara kepulauan yang dibatasi oleh perairan yang benipa lautan. Negara Republik Indonesia memiliki banyak sumber daya alam yang melimpah, dengan kekayaan alam yang melimpah tersebut salah satunya berada pada perairan khususnya lautan Indonesia yang terdapat banyaknya biota laut. Indonesia mempunyai pesona alam serta keanekaragaman sumber daya alam hayati baik di daratan maupun di lautan. Kekayaan alam yang terkandung didalamnya dikuasai oleh Negara dan digunakan dengan skala besar demi kemakmuran rakyat. Pemyataan demikian memberi kebebasan masyarakat untuk memanfaatkan hasil alam guna kepentingan hidup masyarakat setiap harinya serta memanfaatkan hasil yang lebih menguntungkan 
dengan cara menjual suatu produk yang berbahan dasar berasal dari hasil alam, salah satu penghasilan dari masyarakat Indonesia yaitu dengan dilakukannya suatu perdagangan dari hasil kekayaan laut niisalkan melakukan jual-beli lobster yang mempunyai nilai jual sangat tinggi. Namun, dampak dari kebebasan tersebut masyarakat sering menyalahgunakan tindakan terlarang tersebut dengan cara penyelundupan bibit lobster yang diekspor. Laut Indonesia memiliki sekitar 8.500 species ikan, 555 species rumput laut dan 950 species biota terumbu karang. Sumberdaya ikan di laut meliputi 37\% dari species ikan di dunia, dimana beberapa jenis diantaranya mempunyai nilai ekonomis tinggi, seperti tuna, udang, lobster, ikan karang, berbagai jenis ikan hias, kekerangan, dan rumput laut. Kekayaan laut yang dimiliki oleh Indonesia tersebut harus dimanfaatkan untuk kesejahteraan rakyat. Hal ini sebagaimana yang telah diatur dalam Pasal 33 ayat (3) Undang-Undang Dasar Negara Republik Indonesia Tahun 1945 (selanjutnya disebut dengan UUD 1945) yang menyatakan bahwa "Bumi dan air dan kekayaan alam yang terkandung di dalamnya dikuasai oleh Negara dan dipergunakan untuk sebesar-besar kemakmuran rakyat" (Hapiz \& Natsir, 2019).

Penyelundupan terjadi disebabkan karena bisnis dari komoditi hasil lautan yang sangat menggiurkan terutama harga lobster yang sangat mahal, dengan cara yang cuku $\mathrm{p}$ mudah dan sederhana, transaksi miliaran rupiah tersebut dapat dilakukan salah satu yang dapat dilakukan dengan melakukan illegal modus yang diperbuat atau dilakukan pada umumnya dengan cara mengakali fasilitas kemudahan ekspnr-impnr yang diberikan oleh Bea Cukai. Saat ini Pemerintah telah melakukan berbagai upaya pencegahan hu kum dan tindakan hukum terhadap penyelundupan hasil laut yang dilarang ekspor, selain merugikan Negara juga dapat membuat biota laut semakin langka dan kerusakan alarm menjadi rusak ditambah dengan kerugian yang mencapai triliunan ru piah.

Negara Vietnam pada beberapa tahun terakhir berfokus pada pengembangkan lobster sebagai produk unggulan mereka guna dapat diperjualbelikan di pasar intemational. Untuk dapat dibudidayakan lobster tersebut dan menjualnya ke pasar intemational dengan harga yang lebih mahal. Menteri Kelautan dan Perikanan menyebut, negara seperti Vietnam memerlukan benih dari negara yang memilikinya. Negara Indonesia menjadi salah satu yang secara diam-diam sudah memasok benih lobster tersebut ke Negara Vietnam dalam beberapa tahun terakhir.

Menurut Selo Sumardjan seperti dikutip Sidik Sunaryo, (2004)mengungkapkan penegakan hukum berkaitan erat dengan usaha menanamkan hukum di dalam amsyarakat yang didasarkan pada sistem nilai-nilai yang berlaku dan jangka waktu menanamkan hukum". Secara konsepsional, inti dari penegakan hukum terletak pada kegiatan menyelaraskan hubungan nilai-nilai yang terjabarkan di dalam kaedah-kaedah yang mantap dan mengejawantah dan sikap tindak sebagai rangkaian penjabaran nilai tahap akhir, untuk enciptakan, memlihara dan mempertahankan kedamaian pergaulan hidup (Soekanto \& Soerjono, 2014). Pendapat lain mengenai penegakan hukum menurut Sudikno Mertokusumo (2012) Hukum berfungsi sebagai perlindungan kepentingan manusia. Agar kepentingan manusia terlindungi, hukum harus dilaksanakan. Pelaksanaan hukum dapat berlangsung secara normal, damai, tetapi dapat terjadi juga karena pelanggaran hukum. Dalam hal ini hukum yang telah dilanggar itu harus ditegakkan, melalui penegakan hukum inilah hukum menjadi kenyataan. Dalam penegakan hukum ada tiga unsur yang selalu harus diperhatikan, yaitu kepastian hukum.

Lobster (Panulirus sp) atau udang karang merupakan salah satu komoditas ekspor dari subsector perikanan Indonesia dan merupakan komponen penting bagi perikanan udang di Indonesia. Komoditas ini perlu lebih dikembangkan karena nilai perdagangan dan potensinya cukup tinggi. Lobster menempati urutan ke empat untuk komoditas ekspor dari bangsa Krustacea setelah marga Penaeus, Metapeaneus, dan Macrobrachium menurut catatan Statistik Indonesia pada Tahun 2005 (Hilal \& Fachri, 2016). Perikanan mempunyai peranan yang penting dan strategis dalam pembangunan perekonomian nasional, terutama dalam meningkatkan perluasan kesempatan kerja, pemerataan pendapatan, dan peningkatan taraf hidup bangsa pada umumnya, nelayan kecil, pembudi daya-ikan kecil, dan pihak-pihak pelaku usaha di bidang perikanan dengan tetap memelihara lingkungan, kelestarian, dan ketersediaan sumber daya ikan (Veronica et al., 2020). Penyeludupan benih lobster yang tidak memperhatikan hukum da sustainability merupakan ancaman terbesar bagi dunia konservasi. Benih lobster sering diburu oleh nelayan untuk diperdagangkan secara illegal. Benih lobster secara keseluruhan merupakan hewan yang selama beberapa tahun terakhir ini mengalami banyakpenangkapan untuk dikembangkan di luar daerah Indonesia serta dijual belikan 
saat masih berukuran benih, dan salah satu benih lobster yang mengalami hal tersebut adalah benih lobster asal Indonesia. Berbeda dengan jenis ikan lain yang rata-rata hanya dijual dalam keadaan ikan dewasa atau dengan mengukur berat satuan dari ikan tersebut, losbter sejak berukuran benih atau dibawah ukuran $8 \mathrm{~cm}$ sudah memiliki harga yang fantastis (Adhiatma \& Putranti, 2019).

Dari hasil paparan diatas dapat dirumuskan tujuan dari penelitian ini untuk mengetahui pengaturan tentang larangan penangkapan bibit lobster. Mengetahui penegakan hukum terhadap tindak pidana penyelundupan bibit lobster.

\section{METODE PENELITIAN}

Metode penelitian dalam penyusunan ini adalah metode penelitian hukum normatif, eksplorasi hukum normatif adalah penelitian hu kum yang tinjauannya disusun dari perspektif yang berbeda, kemudian untuk mengatur eksplorasi yang sah teknik metodologi yang digunakan untuk membicarakan masalah penelitian adalah melalui metodologi hukum dan metodologi teoritis yang memanfaatkan pemikiran dedu katif. Terlebih lagi, atau pendaftaran untuk mendapatkan dan menemukan kebenaran target. Metodologi hukum adalah metodologi yang dilakukan dengan melihat seluruh peraturan perundangundangan yang diidentikkan dengan persoalan hu kum terdekat, sedangkan metodologi terapan adalah metodol ogi yang berangkat dari ajaran dan cara pandang yang tercipta dalam ilmu hu kum untuk menjelaskan pemikiran dengan memberikan pengaturan yang sah, ide yang sah, dan standar yang sah. Sumber dari penelitian ini diperoleh melalui pendekatan-pendekatan dengan mengkaji berdasarkan peraturan perundang-undangan, prinsip-prinsip hukum, maupun doktrin-doktrin hukum untuk menyanggapi tema hukum yang dijumpai untuk mendapatkan pendapat, pemikiran serta pemahaman baru selaku aturan untuk menamatkan kejadian yang terjadi.

\section{HASIL DAN PEMBAHASAN}

\section{Pengaturan Tentang Larangan Penangkapan Bibit Lobster}

Pengaturan tentang larangan penangkapan bibit lobster sudah diatur pada suatu peraturan yaitu suatu Peraturan Menteri KKP Rl (PERMEN-KP) Menteri Kelautan dan Perikanan Republik Indonesia Nomor 1/PERMEN-KP/2015. Namun pada perkembangan yang sedang berlangsung, peraturan tersebut sudah banyak mengalami suatu peru bahan. Pada tanggal 23 December 2016, Pemerintah Republik Indonesia melal ui kementerian Kelautan dan Perikanan Republik Indonesia, lbu Susi Pudjiastuti telah mengeluarkan suatu Peraturan baru yaitu Peraturan Menteri KKP No.56/PermenKP/201 6 Tentang Larangan Penangkapan dan atau Pengeluaran Lobster, Kepiting, dan Rajungan dari wilayah republic Indonesia. Tetapi, peraturan menteri tersebut memiliki suatu tujuan untu $\mathrm{k}$ melindungi keberlangsungan lobster, kepiting, dan rajungan ini justru menjadikan sebuah permen pahit bagi pulu han ribu nelayan di Indonesia.

Menteri Kelautan dan Perikanan Republik Indonesia di tahun periode 2014-20 19 telah mengeluarkan suatu kebijakan beru pa larangan untu k melakukan penangkapan lobster, kepiting, dan rajungan yang dalam keadaan bertelur dan masih di bawah berat 200 gram. Peraturan tersebut tertuang dalam suatu Peraturan Menteri KKP (Permen KP) No 1/2015 dan ditetapkan berlaku mulai awal tahun 2015 Pemerintah Indonesia Melalui Kementerian Kelautan dan Perikanan mengeluarkan suatu Peraturan menteri dimana Peraturan Menteri tersebut dibuat yang disebabkan oleh adanya suatu kerugian yang dialami dari segi pendapatan mau pun dari segi berkurangnya biota laut tersebut di wilayah perairan Indonesia. Menteri kelautan dan perikanan Republik Indonesia beralasan bahwa larangan penangkapan lobster, kepiting dan rajungan dibawah berat 200 gram supaya memiliki nilai tambah yang lebih besar di laut Indonesia. Sebab selama ini pengeluaran lobster, kepiting, dan rajungan beru kuran berat 20 gram sampai 50 gram tiap tahunnya biasa melebihi 5 juta ekor ke Negara Vietnam.

Menteri kelautan dan perikanan republik 1ndonesia mencontohkan bahwa kepiting yang ukuran bohnt mencapai 500 gram yang dalam kondisi bertelur harganya hanya Rp 100.000. Tetapi, bila kepiting tersebut dibiarkan atau tidak ditangkap, maka akan banyak keuntungan yang bisa didapat. Menurut Menteri KKP dari satu ekor kepiting yang dalam kondisi bertelur, jika dibiarkan bertelur dan besar di alam, maka akan menghasilkan kurang lebih 5.000 kali dari satu ekor kepiting atau setara dengan 5 ton kepiting yang dihasilkan.

BKIPM yang bertanggung jawab langsung kepada Menteri KKP Republik Indonesia tersebut yang diatur didalam peraturan menteri PER.15/MEN/20 10 dimana BKIPM memiliki beberapa fungsi 
penting diantaranya adalah:

1. Penyusunan suatu kebijakan teknis, rencana dan program perkarantinaan ikan serta mengendalikan mutu dan keamanan hasil perikanan.

2. Pelaksanaan perkarantinaan ikan dan pengendalian mutu sena keamanan hasil perikanan. Pemantauan, evaluasi, dan pelaporan pelaksanaan perkarantinaan ikan sena pengendalian mutu dan keamanan hasil perikanan dan Pelaksanaan administrasi BKIPM.

3. Penegakan Hukum Terhadap Tindak Pidana Penyelundupan Bibit Lobster

Kata selundup dicirikan sebagai menghindar, terkulai, masuk secara sembunyi-sembunyi atau melawan hukum (salah). Sementara itu, membawa dicirikan sebagai pengiriman produ k terlarang untuk menghindari kewajiban impor atau karena pembajakan barang dagangan yang ditolak (Marpaung, 1991).

Tindak pidana penyelundupan tidak berlaku begitu saja, akan tetapi ada beberapa faktor penting yang menyebabkan terjadinya tindak pidana penyelundupan bibit lobster tersebut, diantaranya adalah sebagai berikut:

1. Faktor Topografi

Besar kecilnya wilayah Negara Kesatuan Republik Indonesia (NKRI) merupakan salah satu variabel yang sangat menggelitik yang menjadi penyebab menyelinapnya benih lobster. Untuk alasan apa itu seharusnya menarik? Hal ini dikarenakan kehebatan kepulauan Indonesia yang terdiri dari ribu an pulau besar dan kecil, diapit oleh dua daratan, tepatnya Asia dan Australia, seperti dua lautan dengan garis pantai yang luas dan negara-negara yang berbatasan langsung yang telah berkembang pesat, keduanya secara mekanis, industri dan SDM. Di bidang moneter, oknumoknum yang tidak dapat diandalkan memanfaatkan hal ini dengan mengadakan bea masu $\mathrm{k}$ dan tindakan impor yang dilakukan secara diam-diam. Cara pengangkutan biasanya terjadi, yakni mel alui jalur depan pantai di luar kawasan pelabu han, dengan menggunakan kapal ke kapal lain, atau melalui pesawat dengan mengontrol bentu k yang dibawa.

2. Faktor Ekonomi

Selain karena faktor geografis, faktor ekonomi menjadi salah satu faktor penting dan meru pakan suatu indikasi besar terjadinya penyelundu pan. Masyarakat yang hendak ingin mendapatkan suatu keuntungan yang lebih banyak guna untuk memenuhi kebutuhan hidup masyarakat sehari-hari, nekat melaku kan upaya penyelundupan. Hal ini sangat terasa di wilayah Indonesia, terutama tingkat kemiskinan yang cenderung tidak pemah ada habisnya dan malah terus bertambah akibat kurangnya lapangan pekerjaan. Faktor tersebutlah yang mendorong masyarakat untuk bisa mendapatkan penghasilan lebih dengan melakukan tindak pidana penyelundupan, sumber daya alam faktor ini turut serta mempengaruhi terjadinya penyelundu pan. Hal ini dapat kita lihat dari bahan-bahan mentah yang dibutuhkan nleh negara lain, atau bahkan hewan-hewan yang dilindungi serta biota laut yang membuat negara lain ingin memilikinya dengan cara membeli bibit dan membudidayakan hingga besar, sehingga hasil penjualannya lebih menguntungkan.

3. Mentalitas Petugas dan Masyarakat

Para pelaku penyelundupan pada u mumnya bukanlah orang-orang yang memiliki masalah kecil, akan tetapi pada umuninya orang-orang yang memiliki modal yang begitu besar. Jadi apabila para petugas tidak dapat menahan beban tanggung jawab untuk melakukan pekerjaannya secara baik dan jujur, maka para petugas tersebut tentu dapat dipengaru hi oleh oknum yang tidak bertanggung jawab yang melakukan penyelundup secara licik agar dapat meloloskan barang selundupan mereka tersebut tanpa adanya proses hukum. Usaha penanggulangan tindak pidana ini juga membutu hkan partisipasi masyarakat, namun dalam kenyataannya sering dirasakan masyarakat kurang berpartisipasi dalam memberantas tindak pidana penyelundupan. Hal ini disebabkan karena adanya suatu keuntungan yang diperoleh masyarakat.

4. Pasar Gelap

Pasar gelap adalah suatu keadaan dimana barang yang sama persis dengan aslinya tetapi bu kan barang original atau hanya seperti replika atau banyak orang menyebutnya barang tolak (Bagir Manan 2009:51). Perbuatan yang tidak dapat dikehendaki yaitu suatu perbuatan beru pa perbuatanperbuatan yang bersifat negatif. Yang artinya bahwa, demonstrasi tidak dapat diungkapkan dan di ucapkan dibatasi dalam pedoman hukum (Halim, 2005). Substansi undang-undang dan pedoman adalah sebagai kegiatan yang dilarang atau dibatasi. Jadi pada tingkat dasar, setiap kegiatan ini diizinkan kecuali demonstrasi dilarang oleh pengesahan. Sementara itu , aktivitas yang dihalangi 
diarahkan jika ada keraguan atau standar yang berlaku baik dalam stru ktur tersusun mau pun dalam komposisi tidak tertulis.

Dua isu fokus dalam strategi pidana dengan memanfaatkan jaminan masalah (hukum pidana) adalah masalah penentuan:

1. Setiap kegiatan yang dapat digunakan sebagai demonstrasi kriminal, dan

2. Persetujuan apa yang mungkin digunakan atau dipaksakan pada pihak yang bersalah.

Dalam hal perbuatan tindak pidana penyelundu pan yang sering terjadi di Negara Indonesia, sanksi pidana tersebut telah diatur didalam U U No.17 tahun 2006 tentang kepabeanan, sanksi pidana terhadap penyelundu pan sebagaimana yang telah diatur pada Pasal 102, Pasal 102A, dan Pasal 102 B tersebut, pada dasar nya menerapkan persetujuan pidana sebagai pokok, yaitu penahanan dan denda khusus yang merupakan persetujuan pidana gabungan (digabungkan), dengan berfokus pada penggunaan persetujuan penahanan terlebih dahulu dan kemudian diikuti oleh otorisasi pidana gabungan. Penggunaan otorisasi kriminal seperti ini menunjukkan bahwa pelakun ya melakukan kesalahan yang men yelinap bergantung pada persetujuan pidana ganda yang benar-benar serius, yaitu penahanan khusus dari satu perspektif dan lebih jauh lagi denda. $\mathrm{N}$ amun demikian, jika denda tidak bisa dibayar dengan tambahan Pasal $30 \mathrm{~K}$ UHP, itu sangat merugikan negara. Permohonan tersebut muncul sebagai persetujuan pidana agreg at, dengan alasan perbuatan salah membaca merupakan jenis perbuatan salah atau perbuatan salah yang merugikan kepentingan pendapatan negara, melen yapkan kemantapan perekonomian negara, dan merusak potensi penerima an negara yang diharapkan dapat kembali. perbaikan publik yang berkaitan dengan bantuan pemerintah, semua hal dipertimbangkan. tunduk pada dukungan pidana yang bersifat elektif sehingga Undang- Undang Kepabeanan dilaksanakan untu k membangun pendapatan negara dan perdagangan asing. Dalam hal persetujuan pidana tidak didefinisikan secara agregat, bagian dari pendapatan mnneter negara tidak difokuskan pada, dengan alasan bahwa persetujuan pidana total hanya dibatasi pada mereka yang diharapkan untuk menjaga otoritas otoritas publik, mengabaikan minat yang lebih menonjol berfokus pada pengembalian kerugian Negara ( Yudi Wibnwo:2013: 76) .

\section{SIMPULAN DAN SARAN}

\section{Simpulan}

Simpulan dari penelitin ini yakni peraturan penangkapan bibit lobster telah diatur dalam Peraturan Menteri Kelautan dan Perikanan Republik Indonesia Nomor 56/PERMEN-KP/201 6 Tentang Larangan Penangkapan dan/atau Pengeluaran Lobster, Kepiting, dan Rajungan. Namun di tahun 2020 Kementerian Kelautan dan Perikanan Republik Indonesia kembali mengeluarkan peraturan Nomor I 2/PERMEN-KP/2020 tentang pengelolaan Lobster, Kepiting, dan Rajungan, yang secara tidak langsung membu ka kembali ekspor benih lobster di Indonesia. Penegakan hukum terhadap tindak pidana penyelundu pan diatur dalam Undang-U ndang Nomor 17 tahun 2006 Tentang Peru bahan atas Undang-Undang Nomor 10 tahun 1995 Tentang Kepabeanan yang menjelaskan definisi dari penyelundu pan baik dari segi ekspor maupun impor. Sanksi pidana penyelundupan sebagaimana telah diatur dalam ketentuan Pasal 102, 102A, dan 102B Undang- Undang N omor 17 tahun 2006 pada dasam ya menerapkan sanksi pidana berupa pidana penjara dan pidana denda yang merupakan sanksi pidana gabungan, berdasarkan su bsider Pasal 30 KUHP yang mengatur tentang sanksi denda.

\section{Saran}

Harus ada pengelolaan yang lebih ketat, terutama untu $\mathrm{k}$ biota laut dan bu mi yang akan diselundu pkan. Undang-undang Nomor 17 Tahun 2006 seharusnya memuat pedoman tentang pembatasan tarif pada jenis barang dagangan yang tidak ingin dikirim keluar. Ada persyaratan untu k menerapkan pedoman yang sah terhadap penyelundu pan kehidupan laut atau makhluk yang dilindungi, yang berisi larangan dan kewenangan pidana secara eksplisit bagi individu yang membajak makhlu $\mathrm{k}$ air dan darat. Bootlegger harus diberi informasi tentang ada tidaknya aset yang mereka butu hkan untu $\mathrm{k}$ menyelinap dan hasil dari tindakan penyelundu pan, sehingga ada pembelajaran bagi para pelakunya baik melalui siklus yang sah atau setelah dibebaskan dari jerat yang sah sehingga agar tidak mengulangi perbuatan salah.

\section{DAFTAR PUSTAKA}


Marpaung. L. (1991). Tindak Pidana Penyeludupan dan Pemecahan. PT. Gramedia Pustaka Utama. Jakarta.

Halim. (2005). Politre Hukum Piflune. Pustaka Pelajar, Yogyakarta.

Wibowo, Y. (2013). Tindak Pidana Penyeludupan di Indonesin. Sinar Grafika, Jakarta.

Veronica, A., Nawawi, K., \& Erwin. (2020). Penegakan Hukum Pidana Terhadap Penyelundupan Baby Lobster. Joumal of Criminal, Vol.1 (3).

Adhiatma, F., \& Putranti, I. R. (2019). Efektivitas (Rpoa) Regional Plan of Action Dalam Penanggulangan Iuu Fishing Studi Kasus: Penyulundupan Ilegal Benih Lobster

Hilal, K., \& Fachri, Y. (2016). Kepentingan Indonesia Melarang Ekspor Benih Lobster Ke Vietnam Tahun 2015. Jom Fisip, Vol. 3(2).

Hapiz, H., \& Natsir, M. (2019). Tinjauan Kriminologis Tentang Tindak Pidana Penyelundupan Benih Lobster (Studi Di Daerah Kabupaten Lombok Tengah). Jurnal Ilmiah.

Sunaryo, S. (2004). Sistem Peradilan Pidana. Universitas Muhammadiyah Malang.

Soekanto, \& Soerjono. (2014). Faktor-Faktor Yang Mempengaruhi Penegakan Hukum. Ui Pres. Jakarta.

Mertokusumo, S. (2012). Teori Hukum. Cahaya Atma Pustaka. Jakarta. 